\title{
Genetic alterations and protein expression in combined small cell lung cancers and small cell lung cancers arising from lung adenocarcinomas after therapy with tyrosine kinase inhibitors
}

\author{
Xiaohua Shi ${ }^{1}$, Huanli Duan ${ }^{1}$, Xuguang Liu ${ }^{1}$, Liangrui Zhou ${ }^{1}$, Zhiyong Liang ${ }^{1}$ \\ ${ }^{1}$ Department of Pathology, Peking Union Medical College Hospital, Chinese Academy of Medical Science, Beijing, China \\ Correspondence to: Zhiyong Liang, email: liangzhiyong1220@yahoo.com
}

Keywords: combined small cell lung cancer, adenocarcinoma, epidermal growth factor receptor, KRAS, retinoblastoma protein

Received: January 08, 2016

Accepted: April 11, 2016

Published: April 28, 2016

\section{ABSTRACT}

There are $\mathbf{2}$ hypotheses regarding the mechanism underlying the adenocarcinoma (AD) to small cell lung cancer (SCLC) transition in patients receiving Tyrosine kinase inhibitor (TKI) therapy: 1) AD gives rise to SCLC owing to the pressure of the TKI therapy, and 2) the SCLC coexists with the AD de novo, but is not detected in biopsy specimens of the heterogeneous tumor. In this study, we try to address this issue by examination the genetic alteration and protein expression profile between SCLC arising from AD, and SCLC in combined small cell lung cancers (CSCLC). In the former, the SCLC had the same genetic profile as the AD, and we strongly suggest that the transition was a consequence of TKI therapy. In the latter, genetic alterations and protein expression tended to differ between the NSCLC and SCLC components of the CSCLC. The results showed that EGFR and KRAS mutation were found in 1 but not both component of CSCLC, and the NSCLC component usually expressed the EGFR and RB1 proteins, whereas the SCLC component did not. This finding indicates that the NSCLC and SCLC components arose separately and that CSCLC are unsuitable for TKI therapy despite the presence of sensitive EGFR mutations.

\section{INTRODUCTION}

Small cell lung cancers (SCLC), which account for $15 \%$ of lung cancers, differ histologically and biologically from non-small cell lung cancers (NSCLC), which account for $85 \%$ of all lung cancers [1]. Combined SCLC (CSCLC) is a mixture of SCLC and NSCLC, in which the NSCLC component can be adenocarcinoma (AD), squamous cell carcinoma (SCC), or large cell carcinoma. CSCLC is rare, accounting for only $2 \%$ to $10 \%$ of SCLC $[2,3]$. The treatment strategies for SCLC and NSCLC differs: concurrent chemotherapy and radiation therapy for most SCLC, and neoadjuvant chemotherapy and complete resection for early-stage NSCLC [4]. There is still no wellestablished treatment for CSCLC because of its rarity and complexity.

The introduction of tyrosine kinase inhibitors (TKI) dramatically has greatly improved the treatment of AD with EGFR mutations. However, acquired resistance to TKI usually develops after about 12 months of TKI treatment [5]. There are several mechanisms for the development of resistance, one of them being the histological transformation from AD to SCLC, as confirmed by repeated biopsy of the SCLC [6]. Whether the SCLC component exists before TKI treatment or is a consequence of treatment is controversial.

It is generally accepted that NSCLC originates in the bronchoalveolar junction or in the basal cells of the bronchial membrane, whereas SCLC originates in the neuroendocrine cells underneath the basal membrane of the bronchi [7]. The origin of CSCLC is unclear; the two components may give rise to each other or simply coexist in a single tumor.

In this study, we reported 11 cases of CSCLC and 2 cases of SCLC that arose from AD after TKI treatment. We focused on the clinicopathological, immunohistochemical, and genetic profiles of the distinct components of these tumors to determine their origin. 


\section{RESULTS}

\section{Clinical characteristics of the patients}

Clinical characteristics of the patients are summarized in Table 1. Thirteen patients were divided into 4 groups. Group 1 contained two patients with SCLC originating from $\mathrm{AD}$ owing to acquired resistance after TKI therapy. Group 2 contained four patients with CSCLC, whose NSCLC components were AD. Group 3 contained five patients with CSCLC, whose NSCLC component was SCC. Group 4 contained two patients with CSCLC, whose NSCLC component were SCC and AD.

The ages of the two patients in Group 1 were 46 and 48 years old, respectively; case 1 was a male and case 2 was a female, and neither had a smoking history. In case 1, the patient was diagnosed with stage IV AD and had received TKI (gefitinib) therapy. The patient obtained stable disease (SD) for 10 months and died 11 months after being diagnosed with SCLC. In case 2, the patient was diagnosed with stage II AD and received surgery followed by chemotherapy. Recurrence was noticed after a follow-up period of 31 months. TKI therapy was then administrated, resulting in SD of 61 months. Then she had repeated biopsy of the lesion, which was found to have transformed to SCLC. Her treatment was consequently switched to chemotherapy and radiotherapy. She is now surviving with the tumor. The follow-up time is 139.6 months. In both patients, the SCLC was located at a different site from the $\mathrm{AD}$, and re-biopsy results confirmed the diagnosis.

The average age of the eleven patients with CSCLC (groups 2-4) was 66.5 years (range: $57-79$ years); all were men, 10 were smokers, and none had received TKI therapy. Clinical stage was determined according to the pathological and radiological information: two patients at stage I, one at stage II, three at stage III, and two at stage IV. The stages were not determined for the remaining three patients. Because their disease was advanced. three patients were biopsied only. Seven patients underwent pneumonectomy. One patient had thoracotomy, but the surgery did not proceed owing to the diagnosis of CSCLC (based on the result of frozen sections) and the advanced stage of the disease. Seven of the eight surgical patients received postoperative chemotherapy or radiation after being informed the benefits and risks of the treatments; one patient refused further therapy. Recurrence was noticed in eight of ten patients at averagely13.9 months after diagnosis. Six of the ten patients died at averagely 14.7 months after diagnosis. At the end of the follow-up period, one patient was alive without disease, and two were alive with disease.

\section{Pathological characteristics}

The pathological characteristics of the patients are presented in Table 2. The SCLC component in all cases was confirmed by immunohistochemistry (IHC), which showed positive staining of chromogranin A $(\mathrm{CgA})$, Synaptophysin (Syn), and a high proliferation index (high percentage of Ki-67-positive cells) (Figure 1).

Among the eleven CSCLC cases (groups 2-4), six had distinguishable SCLC and NSCLC components. The average size of the SCLC component was $2.1 \mathrm{~cm}$ (range: $0.7-3.5 \mathrm{~cm}$ ), while the average size of the NSCLC component was $3.1 \mathrm{~cm}$ (range: $1.5-5 \mathrm{~cm}$ ). In three of the eleven cases in which the SCLC and NSCLC component were mixed together, the ratio of the two different components was estimated according to the morphology of the HE-stained samples. The most common growth pattern of the $\mathrm{AD}$ component was the alveolar pattern (three cases); other patterns included micropapillary (one case), solid (one case), and lepidic (one case). The differentiation status of the SCC component was rated as well- (three cases), moderately- (two cases), or poorlydifferentiated (two cases). Positive node metastasis was observed in three of five cases; the SCLC components metastasized in two cases, and metastases of both the SCLC and AD components were observed in one case. Three of five cases showed involvement of the major bronchi, while four of eight cases showed involvement of the pleura. Lymphovascular invasion was identified in six of eight cases.

\section{Immunohistochemical results and genetic profiles}

The immunohistochemical and genetic profiling results are summarized in Table 3 .

In Group 1, the primary AD and recurrent SCLC had identical EGFR mutations (a L858R mutation in exon 21 in case 1 and an exon 19 deletion in case 2). In the CSCLC cases (groups 2-4), 2 mutations were identified : an EGFR mutation (L858R in exon 21) in the AD component of case 2 in Group 2, and a KRAS mutation (G12V in exon 2) in the SCLC component of case 2 in Group 3. No mutation in $B R A F, A L K$, or PIK3CA was found in any of the cases in Group 1-4.

In Group 1, immunohistochemical results were unavailable for the $\mathrm{AD}$ component in case 1 and for both component in case 2 because of limited tissue amount or quality. In case $1, \mathrm{RB} 1, \mathrm{p} 53$, and EGFR were not expressed in the SCLC component, while in case 2, EGFR was amplified in the $\mathrm{AD}$ component.

In groups 2-4 (the eleven CSCLC cases), p53 was not expressed in the SCLC component in three cases or in the NSCLC component in four cases. RB1 expression was negative in the SCLC component in eight cases, but was negative in the NSCLC component in only three cases. EGFR expression was positive in the NSCLC components in ten cases, but was positive in the SCLC component in only one case.

In summary, the same kind of $E G F R$ mutations was observed in both the AD and SCLC in Group 1. In contrast, there were differences in the gene mutation profiles and 
Table 1: Clinical characteristics of the patients

\begin{tabular}{|c|c|c|c|c|c|c|c|c|c|c|c|}
\hline Group & $\begin{array}{c}\text { Case } \\
\#\end{array}$ & Sex & $\begin{array}{c}\text { Age } \\
\text { (years) }\end{array}$ & Smoking & TKI & $\begin{array}{c}\text { Biopsy } \\
\text { or } \\
\text { Surgery }\end{array}$ & $\begin{array}{l}\text { Final } \\
\text { Stage }\end{array}$ & Recur & $\begin{array}{c}\text { RFS } \\
\text { (months) }\end{array}$ & Death & $\begin{array}{c}\text { OS } \\
\text { (months) }\end{array}$ \\
\hline \multirow{2}{*}{$\begin{array}{c}1 \\
\text { AD to } \\
\text { SCLC }\end{array}$} & $1-1$ & M & 46 & $\mathrm{~N}$ & $\mathrm{Y}$ & B & IV & Y & 10 & $\mathrm{Y}$ & 21.3 \\
\hline & $1-2$ & $\mathrm{~F}$ & 48 & $\mathrm{~N}$ & Y & B & II & Y & 31 & $\mathrm{~N}$ & 139.6 \\
\hline \multirow{4}{*}{$\begin{array}{c}2 \\
\mathrm{SCLC} \\
+\mathrm{AD}\end{array}$} & $2-1$ & M & 79 & Y & $\mathrm{N}$ & S & III & Y & 19.2 & $\mathrm{~N}$ & 19.2 \\
\hline & $2-2$ & M & 71 & $\mathrm{Y}$ & $\mathrm{N}$ & S & I & Y & 11 & $\mathrm{Y}$ & 12 \\
\hline & $2-3$ & M & 66 & Y & $\mathrm{N}$ & S & III & Y & 13 & Y & 14.4 \\
\hline & $2-4$ & M & 61 & Y & $\mathrm{N}$ & B & IV & Y & 12 & Y & 12.8 \\
\hline \multirow{5}{*}{$\begin{array}{c}3 \\
\text { SCLC } \\
+ \text { SCC }\end{array}$} & $3-1$ & M & 71 & $\mathrm{Y}$ & $\mathrm{N}$ & S & NA & Y & 5 & $\mathrm{~N}$ & 71.4 \\
\hline & $3-2$ & M & 62 & $\mathrm{Y}$ & $\mathrm{N}$ & S & III & $\mathrm{N}$ & - & $\mathrm{N}$ & 35.5 \\
\hline & $3-3$ & M & 57 & Y & $\mathrm{N}$ & B & IV & $\mathrm{Y}$ & 25 & $\mathrm{Y}$ & 24.8 \\
\hline & $3-4$ & $\mathrm{M}$ & 66 & Y & $\mathrm{N}$ & $\mathrm{S}$ & I & Y & 6 & $\mathrm{~N}$ & 8.7 \\
\hline & $3-5$ & $\mathrm{M}$ & 74 & Y & $\mathrm{N}$ & B & NA & Y & 18 & Y & 18 \\
\hline \multirow{2}{*}{$\begin{array}{c}4 \\
\mathrm{SCLC} \\
+\mathrm{AD}+ \\
\mathrm{SCC}\end{array}$} & $4-1$ & M & 66 & NA & NA & $\mathrm{S}$ & NA & NA & NA & NA & NA \\
\hline & $4-2$ & M & 58 & Y & $\mathrm{N}$ & $\mathrm{S}$ & II & $\mathrm{N}$ & - & Y & 6.3 \\
\hline
\end{tabular}

TKI: tyrosine kinase inhibitor; Recur: recurrence; RFS: recurrence-free survival; OS: overall survival; AD: adenocarcinoma; SCLC: small cell lung cancer; SCC: squamous cell carcinoma; F: female; M: male; Y: yes; N: no; NA: not available; B: biopsy; S: surgery.

protein expression patterns in the SCLC and NSCLC components of the CSCLC (groups 2-4): Divergent genetic changes were noted in the SCLC and NSCLC component in two cases (EGFR mutation only in the AD component of case 2 in Group 2, and K-ras mutation only in the SCLC component of case 2 in Group 3). EGFR was amplified more often in the NSCLC component, whereas loss of RB1 was more common in the SCLC component.

\section{DISCUSSION}

The present study reported the clinicopathological, immunohistochemical, and genetic characteristics of two SCLC cases that arose from AD after TKI therapy and eleven CSCLC cases. Our results showed differences between the "transitioned" tumors (AD to SCLC) and the combined tumors (CSCLC): the former often had the same $E G F R$ mutations before and after the transition, while the latter expressed RB1 and EGFR in the NSCLC component more frequently than that in the SCLC component, $E G F R$ and KRAS mutation was found in 1 but not both components of CSCLC.
In our study, all 11 patients with CSCLC were male smokers, which was consistent with the work of $\mathrm{Lu}$ et al. [8]. EGFR mutations were identified in one patient with combined SCLC and AD, but in zero patients with combined SCLC and SCC. Such mutation rate is much lower than that for lung $\mathrm{AD}$ in Asian populations, but is consistent with the data reported for CSCLC [9]. Table 4 summarizes the eight previously published cases of CSCLC with EGFR mutations, and here, we added an additional case. In the eight previous cases, the average age was 64 years; four patients were women and four were men. There were more smokers compared to non-smokers (five versus three). In Asian populations, young nonsmoking women diagnosed with $\mathrm{AD}$ are likely to have an $E G F R$ mutation unique to them [12]. This is not the case for CSCLC, as was shown in Table 4. In our study, the patients in Group 1 (AD recurring as SCLC) were young nonsmokers, so it was with AD patients that harbored EGFR mutations.

There are two hypotheses regarding the mechanism underlying the $\mathrm{AD}$ to SCLC transition in patients receiving TKI therapy: 1) AD gives rise to SCLC owing to 
Table 2: The pathological characteristics of the patients

\begin{tabular}{|c|c|c|c|c|c|c|c|c|c|c|c|}
\hline \multirow{2}{*}{ Group } & \multirow{2}{*}{$\begin{array}{c}\text { Case } \\
\#\end{array}$} & \multirow{2}{*}{ Separate } & \multicolumn{3}{|c|}{ Tumor Size (cm) } & \multirow{2}{*}{$\underset{\text { pattern }}{\mathrm{AD}}$} & \multirow{2}{*}{$\begin{array}{c}\text { SCC } \\
\text { Differentiation }\end{array}$} & \multirow{2}{*}{ Node } & \multirow{2}{*}{$\begin{array}{l}\text { Invol of } \\
\text { Bronch }\end{array}$} & \multirow{2}{*}{$\begin{array}{c}\text { Invol } \\
\text { of } \\
\text { Pleura }\end{array}$} & \multirow{2}{*}{ LVI } \\
\hline & & & AD & SCLC & SCC & & & & & & \\
\hline \multirow{2}{*}{1} & $1-1$ & $\mathrm{Y}$ & 5 & 1.5 & & Acinar & - & - & - & - & - \\
\hline & $1-2$ & $\mathrm{Y}$ & 2.3 & $\mathrm{NA}$ & - & Acinar & - & - & - & - & - \\
\hline \multirow{4}{*}{2} & $2-1$ & $\mathrm{Y}$ & 1.5 & 3.5 & - & Micropap & - & Y & $\mathrm{N}$ & $\mathrm{N}$ & $\mathrm{Y}$ \\
\hline & $2-2$ & $\mathrm{Y}$ & 1.8 & 1.8 & - & Lepidic & - & - & - & $\mathrm{N}$ & $\mathrm{Y}$ \\
\hline & $2-3$ & $\mathrm{~N}$ & $3.5,30 \%$ & $70 \%$ & - & Acinar & - & $\mathrm{Y}$ & $\mathrm{N}$ & $\mathrm{Y}$ & $\mathrm{Y}$ \\
\hline & $2-4$ & $\mathrm{~N}$ & NA & NA & - & Acinar & - & - & - & - & - \\
\hline \multirow{5}{*}{3} & $3-1$ & Y & - & 0.7 & 2.8 & - & Poor & - & - & $\mathrm{Y}$ & $\mathrm{N}$ \\
\hline & $3-2$ & Y & - & 1.2 & 5 & - & Moderate & Y & Y & $\mathrm{Y}$ & $\mathrm{Y}$ \\
\hline & $3-3$ & Y & - & 3.5 & 2.9 & - & Well & - & - & - & - \\
\hline & $3-4$ & $\mathrm{~N}$ & - & $\begin{array}{c}6 \\
20 \%\end{array}$ & $80 \%$ & - & Well & $\mathrm{N}$ & $\mathrm{Y}$ & $\mathrm{N}$ & $\mathrm{Y}$ \\
\hline & $3-5$ & $\mathrm{~N}$ & - & NA & NA & - & Moderate & - & - & - & - \\
\hline \multirow[b]{2}{*}{4} & $4-1$ & $\mathrm{~N}$ & $2.62 .5 \%$ & $2.5 \%$ & $95 \%$ & Solid & Poor & - & - & $\mathrm{N}$ & $\mathrm{N}$ \\
\hline & $4-2$ & $\mathrm{Y}$ & $5 \% *$ & 2.1 & $\begin{array}{c}4.5 \\
95 \%\end{array}$ & Acinar & Well & $\mathrm{N}$ & Y & Y & $\mathrm{Y}$ \\
\hline
\end{tabular}

AD: adenocarcinoma; SCLC: small cell lung cancer; SCC: squamous cell carcinoma; Invol of Bronch: involvement of the bronchus; Invol of Pleura: involvement of the pleura; LVI: lymphovascular invasion; Y: yes; N: no; NA: not available; Micropap: micropapillary.

*The AD component is mixed with SCC component.

the pressure of the TKI therapy, and 2) the SCLC coexists with the $\mathrm{AD}$ de novo, but is not detected in biopsy specimens of the heterogeneous tumor [13]. Table 5 summarizes the 18 previously published cases in which AD recurred as SCLC after TKI therapy. This summary shows that the $\mathrm{AD}$ and SCLC have identical EGFR mutations in most cases, which is in concordance with the two cases described in our study. This observation prompted us to investigate the genetic status of CSCLC, especially those with an AD component. Only a few studies have examined the genetic differences between the AD and SCLC components of CSCLC, and most of them focused on a single gene (e.g., EGFR) [8, 9]. In our study, we used a lung cancer gene panel to assess multiple genetic alterations, not only in four CSCLC with SCLC and AD components, but also in five CSCLC with SCLC and SCC components. The results of our analysis showed genetic disparities between SCLC and AD or SCC, most notably in terms of EGFR and KRAS mutations.
As shown in Table 4, three of the eight cases of CSCLC with known EGFR mutations also showed different genetic alterations in these components. Taken together, the present study showed that SCLC arising from AD was different from the SCLC component of CSCLC in terms of their genetic profiles. These results suggested that SCLC originated from AD because of TKI therapy, whereas the two components of CSCLC arised separately, and form a blended tumor. Although the clear mechanism of transition from AD to SCLC remains unknown, it is believed that the existence of a pluripotent stem cell population and the AD phenotype can switch to SCLC under the positive selection of EGFR TKI $[9,17]$.

In addition to genetic differences, protein expression differences detected by IHC were noticed in the two components of the CSCLC. Our results showed that down regulation of $\mathrm{RB} 1$ protein expression was more common in the SCLC component than the NSCLC component of CSCLC. The loss of the RBI gene is 
observed in almost all cases of SCLC, including one case in which the SCLC was derived from an AD. This result suggested that the mutation or loss of $R B 1$ could be a characteristic feature of SCLC [24]. EGFR mutations have also been found in SCLC; however, SCLC with $E G F R$ mutations is less responsive to TKI therapy than lung AD with EGFR mutations. Although SCLC arising from $\mathrm{AD}$ after TKI therapy harbors the same EGFR mutations before and after transition, EGFR amplification is often lower in the SCLC than in the AD, which may account for the worse response of SCLC to TKI therapy [24]. In our study, IHC was used to assess EGFR protein expression in the 2 components of the CSCLC. Our results showed that EGFR was not frequently expressed in the SCLC component (negative results in ten of the eleven cases). This finding indicated that TKI might not be suitable for CSCLC treatment, despite the presence of EGFR mutations.

The present study is subjected to the following limitations. First, because both AD to SCLC transition and CSCLC are rare conditions, we were unable to enroll sufficient cases in the present study to demonstrate a statistical significance. Second, while we have sought to provide extra evidence to support our hypotheses that TKI induced AD to SCLC transition and SCLC and NSCLC arise separately in CSCLC by including previously reported cases in the discussion section, we were unable to draw a definitive conclusion without more substantial evidences. Given the limitations mentioned above, we hope to increase our sample size in the future and look for more direct evidences to further prove the conclusions.

In summary, there were clinical, immunohistochemical, and genetic differences between SCLC arising from $\mathrm{AD}$, and CSCLC. First, our results of identical EGFR mutation in AD and SCLC supported that the transition was a consequence of TKI therapy. Secondly, genetic alterations and protein expression were different between the NSCLC and SCLC components of the CSCLC. Specifically, EGFR was found only in the AD component of one CSCLC and KRAS mutation was identified in the SCLC component of another CSCLC. The NSCLC component usually expressed the EGFR and RB1 proteins more often than the SCLC component in CSCLC. ALL these finding supported that CSCLC is a collision tumor and it was unsuitable for TKI therapy despite the presence of EGFR mutations.

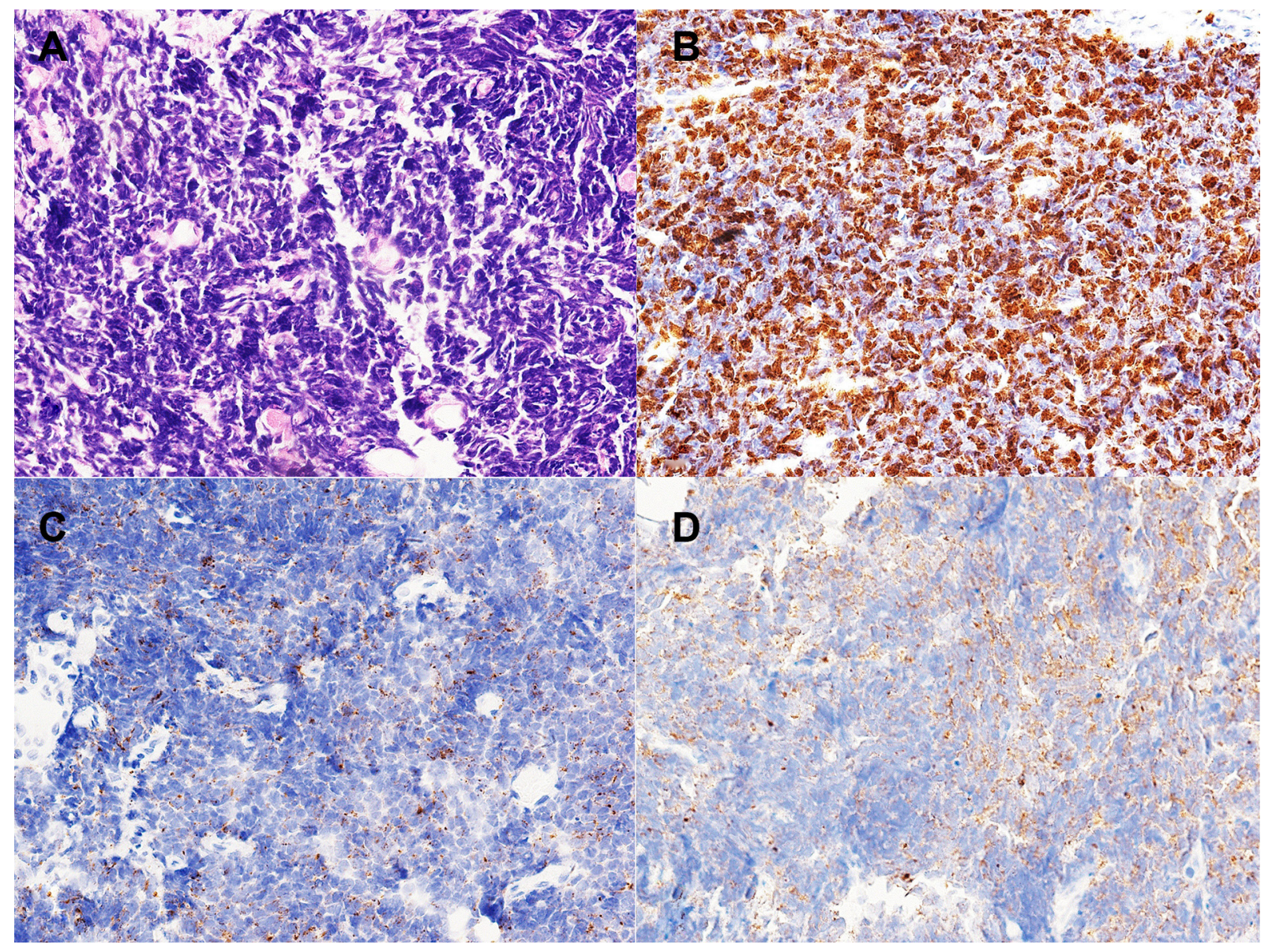

Figure 1: Morphology and immunohistochemistry of small cell lung carcinoma (SCLC). (A) Morphology of SCLC ( $\times 40)$; (B) Ki-67 index is about $90 \%$ in SCLC $(\times 40)$; (C) Syn immunostain is positive in SCLC. $(\times 40)$; (D) CgA immunostain is positive in SCLC. $(\times 40)$. 
Table 3: The immunohistochemical and genetic profiling results of the patients

\begin{tabular}{|c|c|c|c|c|c|c|c|c|c|c|c|c|c|c|}
\hline \multirow{2}{*}{ Item } & \multirow{2}{*}{$\begin{array}{c}\text { Compon } \\
\text { ent }\end{array}$} & \multicolumn{2}{|c|}{ Group 1} & \multicolumn{4}{|c|}{ Group 2} & \multicolumn{5}{|c|}{ Group 3} & \multicolumn{2}{|c|}{ Group 4} \\
\hline & & 1-1 & $1-2$ & $2-1$ & $2-2$ & $2-3$ & $2-4$ & 3-1 & $3-2$ & 3-3 & $3-4$ & $3-5$ & 4-1 & 4-2 \\
\hline \multirow{3}{*}{ p53 } & $\mathrm{AD}$ & NA & NA & 1 & 0 & 1 & 1 & & & & & & 1 & 1 \\
\hline & SCLC & 0 & NA & 0 & 1 & 1 & 0 & 1 & 1 & 1 & 1 & 0 & 1 & 1 \\
\hline & SCC & & & & & & & 0 & 0 & 1 & 1 & 0 & 1 & 1 \\
\hline \multirow{3}{*}{ RB1 } & $\mathrm{AD}$ & NA & NA & 0 & 0 & 1 & 1 & & & & & & 1 & 0 \\
\hline & SCLC & 0 & NA & 0 & 0 & 0 & 0 & 0 & 1 & 0 & 0 & 0 & 1 & 1 \\
\hline & SCC & & & & & & & 1 & 1 & NA & 1 & 1 & 1 & 1 \\
\hline \multirow{3}{*}{$\begin{array}{c}\text { EGFR } \\
\text { IHC }\end{array}$} & $\mathrm{AD}$ & NA & 1 & 1 & 1 & 1 & 1 & & & & & & 1 & 1 \\
\hline & SCLC & 0 & NA & 0 & 0 & 0 & 0 & 0 & 0 & 1 & 0 & 0 & 0 & 0 \\
\hline & SCC & & & & & & & 1 & 1 & 1 & 0 & 1 & 1 & 1 \\
\hline \multirow{3}{*}{$\begin{array}{c}E G F R \\
\text { mutation }\end{array}$} & $\mathrm{AD}$ & $\begin{array}{c}\text { E21 } \\
\text { L858R }\end{array}$ & $\begin{array}{l}\text { E19 } \\
\text { DEL }\end{array}$ & WT & $\begin{array}{c}\text { E21 } \\
\text { L858R }\end{array}$ & WT & WT & & & & & & WT & WT \\
\hline & SCLC & $\begin{array}{c}\text { E21 } \\
\text { L858R }\end{array}$ & $\begin{array}{l}\text { E19 } \\
\text { DEL }\end{array}$ & WT & WT & WT & WT & WT & WT & WT & WT & WT & WT & WT \\
\hline & SCC & & & & & & & WT & WT & WT & WT & WT & WT & WT \\
\hline \multirow{3}{*}{$\begin{array}{c}\text { KRAS } \\
\text { mutation }\end{array}$} & $\mathrm{AD}$ & WT & WT & WT & WT & WT & WT & & & & & & WT & WT \\
\hline & SCLC & WT & WT & WT & WT & WT & WT & WT & $\begin{array}{c}\text { E2 } \\
\text { G12V }\end{array}$ & WT & WT & WT & WT & WT \\
\hline & SCC & & & & & & & WT & WT & WT & WT & WT & WT & WT \\
\hline
\end{tabular}

IHC: immunohistochemistry, RB1: retinoblastoma 1; EGFR: epidermal growth factor receptor; AD: adenocarcinoma; SCLC: small cell lung cancer; SCC: squamous cell carcinoma; NA: not available; WT: wild type; E: exon; 0: negative; 1: positive.

Table 4: CSCLC with EGFR mutation in review of literature

\begin{tabular}{|c|c|c|c|c|c|c|c|}
\hline Author & Year & $\begin{array}{c}\text { NSCLC } \\
\text { Component }\end{array}$ & $\begin{array}{c}\text { Age } \\
\text { (years) }\end{array}$ & Sex & Smoking & $\begin{array}{c}\text { EGFR } \\
\text { Mutation }\end{array}$ & $\begin{array}{c}\text { EGFR } \\
\text { Amplication }\end{array}$ \\
\hline $\begin{array}{c}\text { Fukui et al. } \\
\text { [9] }\end{array}$ & 2007 & $\mathrm{AD}$ & 62 & $\mathrm{~F}$ & $\mathrm{~N}$ & $\begin{array}{l}\text { E21 L858R } \\
\text { in both }\end{array}$ & NA \\
\hline \multirow{2}{*}{$\begin{array}{l}\text { Tatematsu } \\
\text { et al. [10] }\end{array}$} & \multirow{2}{*}{2008} & $\mathrm{AD}$ & 69 & M & $\mathrm{Y}$ & $\begin{array}{l}\text { E21 L858R } \\
\text { in both }\end{array}$ & Amp in AD \\
\hline & & $\mathrm{AD}$ & 65 & $\mathrm{M}$ & $\mathrm{Y}$ & $\begin{array}{l}\text { E19 DEL in } \\
\text { both }\end{array}$ & Amp in AD \\
\hline \multirow[t]{2}{*}{ Lu et al. [8] } & \multirow[t]{2}{*}{2012} & $\mathrm{AD}$ & 62 & $\mathrm{~F}$ & $\mathrm{~N}$ & $\begin{array}{l}\text { E19 DEL in } \\
\text { both }\end{array}$ & NA \\
\hline & & $\mathrm{SCC}$ & 61 & $\mathrm{M}$ & $\mathrm{Y}$ & $\begin{array}{l}\text { E19 DEL in } \\
\text { SCLC }\end{array}$ & NA \\
\hline \multirow{3}{*}{$\begin{array}{l}\text { Norkowski } \\
\text { et al. [11] }\end{array}$} & \multirow{3}{*}{2013} & $\mathrm{AD}$ & 62 & M & $\mathrm{N}$ & $\begin{array}{l}\text { E18 G719A } \\
\text { and } 21 \text { DEL } \\
\text { in both }\end{array}$ & NA \\
\hline & & $\mathrm{AD}$ & 66 & $\mathrm{~F}$ & $\mathrm{Y}$ & $\begin{array}{l}\text { E19 DEL in } \\
\text { AD }\end{array}$ & NA \\
\hline & & $\mathrm{AD}$ & 65 & $\mathrm{~F}$ & $\mathrm{Y}$ & $\begin{array}{l}\text { E21 L858R } \\
\text { in AD }\end{array}$ & NA \\
\hline
\end{tabular}

NSCLC: non small cell lung cancer; AD: adenocarcinoma; SCC: squamous cell carcinoma; F: female; M: male; DEL: deletion; NA: not available; Amp: amplication. 
Table 5: AD recurred as SCLC after TKI therapy in review of literature

\begin{tabular}{|c|c|c|c|c|c|c|c|c|}
\hline Author & Year & Age & Sex & Smoking & TKI & $\begin{array}{c}\text { EGFR } \\
\text { Mutation } \\
\text { in AD }\end{array}$ & $\begin{array}{c}\text { EGFR } \\
\text { Mutation } \\
\text { in SCLC }\end{array}$ & Others \\
\hline $\begin{array}{l}\text { Zakowski } \\
\text { et al. [14] }\end{array}$ & 2006 & 45 & $\mathrm{~F}$ & $\mathrm{~N}$ & $\mathrm{Y}$ & NA & 19 DEL & \\
\hline $\begin{array}{l}\text { Morinaga } \\
\text { et al. [15] }\end{array}$ & 2007 & 46 & $\mathrm{~F}$ & $\mathrm{~N}$ & Y & $19 \mathrm{DEL}$ & $19 \mathrm{DEL}$ & \\
\hline $\begin{array}{l}\text { Alam } \\
\text { et al. [16] }\end{array}$ & 2008 & 73 & $\mathrm{~F}$ & $\mathrm{~N}$ & Y & L858R & L858R & \\
\hline $\begin{array}{l}\text { Tatematsu } \\
\text { et al. [10] }\end{array}$ & 2008 & 36 & $\mathrm{~F}$ & $\mathrm{~N}$ & Y & L858R & L858R & \\
\hline \multirow{5}{*}{$\begin{array}{l}\text { Sequist } \\
\text { et al. [17] }\end{array}$} & \multirow{5}{*}{2011} & 67 & $\mathrm{~F}$ & $\mathrm{~N}$ & $\mathrm{Y}$ & L858R & L858R & \\
\hline & & 54 & $\mathrm{~F}$ & NA & $\mathrm{Y}$ & 19 DEL & $19 \mathrm{DEL}$ & \\
\hline & & 56 & $\mathrm{~F}$ & NA & $\mathrm{Y}$ & L858R & L858R & $\begin{array}{l}\text { PIK3CA } \\
\text { in SCLC }\end{array}$ \\
\hline & & 40 & $\mathrm{~F}$ & NA & $\mathrm{Y}$ & $19 \mathrm{DEL}$ & $19 \mathrm{DEL}$ & \\
\hline & & 61 & $\mathrm{~F}$ & NA & $\mathrm{Y}$ & L858R & L858R & \\
\hline Ma et al. [18] & 2012 & 65 & $\mathrm{~F}$ & $\mathrm{~N}$ & $\mathrm{Y}$ & L858R & L858R & \\
\hline $\begin{array}{l}\text { Van Riel } \\
\text { et al. [19] }\end{array}$ & 2012 & 42 & $\mathrm{~F}$ & $\mathrm{~N}$ & Y & $19 \mathrm{DEL}$ & $19 \mathrm{DEL}$ & $\begin{array}{c}\text { T790M in } \\
\text { AD after } \\
\text { TKI }\end{array}$ \\
\hline $\begin{array}{l}\text { Popat } \\
\text { et al. [20] }\end{array}$ & 2013 & 46 & $\mathrm{~F}$ & $\mathrm{~N}$ & $\mathrm{Y}$ & $19 \mathrm{DEL}$ & $20 \mathrm{DEL}$ & $\begin{array}{l}\text { Large cell } \\
\text { NEC } \\
\text { identified } \\
\text { on } \\
\text { resistance }\end{array}$ \\
\hline $\begin{array}{l}\text { Watanabe } \\
\text { et al. [6] }\end{array}$ & 2013 & 52 & $\mathrm{~F}$ & $\mathrm{~N}$ & $\mathrm{Y}$ & $19 \mathrm{DEL}$ & 19 DEL & \\
\hline \multirow{2}{*}{$\begin{array}{l}\text { Norkowski } \\
\text { et al. [11] }\end{array}$} & \multirow{2}{*}{2013} & 60 & $\mathrm{~F}$ & $\mathrm{~N}$ & Y & $19 \mathrm{DEL}$ & $21 \mathrm{E} 872 \mathrm{~K}$ & \\
\hline & & 50 & $\mathrm{~F}$ & $\mathrm{~N}$ & $\mathrm{Y}$ & $19 \mathrm{DEL}$ & $19 \mathrm{DEL}$ & \\
\hline $\begin{array}{c}\text { Facchinettir } \\
\text { et al. }[21]\end{array}$ & 2013 & 74 & $\mathrm{~F}$ & $\mathrm{~N}$ & $\mathrm{Y}$ & L858R & L858R & \\
\hline $\begin{array}{l}\text { Hwang } \\
\text { et al. [22] }\end{array}$ & 2015 & 61 & M & Y & Y & $19 \mathrm{DEL}$ & $19 \mathrm{DEL}$ & \\
\hline $\begin{array}{l}\text { Furugen } \\
\text { et al. [23] }\end{array}$ & 2015 & 63 & M & $\mathrm{N}$ & $\mathrm{Y}$ & $19 \mathrm{DEL}$ & $19 \mathrm{DEL}$ & $\begin{array}{l}\text { T790M in } \\
\text { AD after } \\
\text { TKI } \\
\text { in autopsy }\end{array}$ \\
\hline
\end{tabular}

TKI: thyrosine kinase therapy; AD: adenocarcinoma; SCLC: small cell lung cancer; F: female; M: male; DEL: deletion; NA: not available; NEC: neuroendocrine carcinoma. 


\section{MATERIALS AND METHODS}

\section{Patients}

Thirteen patients with a final diagnosis of CSCLC who were biopsied or underwent surgery at Peking Union Medical College Hospital in Beijing, China between January 2010 and December 2014 were enrolled in this study. Among these patients, 2 had an AD that transformed into an SCLC after TKI therapy, and 11 had CSCLC. All final diagnoses were based on the morphology of tumor samples stained with hematoxylin and eosin (HE), and confirmed by immunohistochemistry (IHC) and a review of the HE-stained samples by 2 pathologists, individually.

Clinical information was extracted from a digital or archival database and included patient age, sex, and smoking habits (never-smoker was defined as less than 100 cigarettes lifetime), clinical stages, postoperative treatment methods, and prognosis. Clinical stages were determined at the time of surgery based on the tumornode-metastasis staging system of the 7 th edition of the American Joint Commission on Cancer. Recurrence free survival (RFS) was defined as the time from surgery to relapse or the conclusion of the study. Overall survival (OS) was calculated as the time from surgery to death or the conclusion of the research.

In cases involving surgical procedures, pathological characteristics (e.g., tumor location, involvement of the pleura, lymphovascular invasion, and node metastasis) were collected. This study was approved by the Institutional Review Board of the Peking Union Medical College Hospital.

\section{Immunohistochemistry}

Formalin-fixed, paraffin-embedded tissue samples with a thickness of $4 \mu \mathrm{m}$ were used for IHC. Staining was performed through using a Ventana Benchmark XT autostainer (Ventana Medical Systems Inc., Tucson, AZ, USA) according to the manufacturer's instructions. The proteins examined and the antibodies used included the following: retinoblastoma protein 1 (RB1; 1:50, polyclonal; Abcam, Cambridge, UK), p53 (1:1, monoclonal; MXB , Beijing, China), EGFR (1:500, polyclonal; Roche, Tucson, USA ), chromogranin A (CgA; 1:100, polyclonal; OriGene, Beijing, China), synapsin (Syn ;1:500, polyclonal; DAKO, Carpinteria, CA, USA), Ki-67 (1:500, monoclonal; OriGene), thyroid transcription factor receptor-1 (TTF-1; 1:1, monoclonal; MXB), and p40 (1:500, polyclonal; DAKO). The scoring system used for human epidermal growth factor receptor-2 evaluation was used for EGFR evaluation. In this system, expression is graded from $0-3+$ according to the percentage and intensity of positive cells; 0 and 1 indicate negative expression, and 2 and 3 indicate positive expression. RB1, p53, Ki-67, p40, and TTF-1 were scored as positive if brown nuclear staining was evident. CgA, and Syn were scored as positive if there was brown staining in the cytoplasm.

\section{Genetic alterations}

The NSCLC and SCLC components of the CSCLC that could be distinguished in HE-stained samples were manually macrodissected by a pathologist. DNA was isolated from paraffin-embedded tissue by using a QIAamp DNA FFPE Tissue Kit (Qiagen, Hilden, Germany). DNA concentration was measured by using a Nanodrop 2000 spectrophotometer (ThermoFisher, Wilmington, DE, USA) and further standardized to $20-50 \mathrm{ng} / \mu \mathrm{L}$.

The mutation profiles of the EGFR, KRAS, PIK3CA, and $B R A F$ genes were determined by using the appropriate human gene mutation detection kit from Beijing ACCB Biotech (Beijing, China). Sixty-three hotspot mutations were examined: 45 in exons 18-21 of EGFR, 12 in exons 2 and 3 of $K R A S, 5$ in exons 9 and 20 of PIK3CA, and the $B R A F$ V600E mutation. Quantitative polymerase chain reaction (PCR) was performed by using an Mx3000P PCR system (Agilent, Santa Clara, CA, USA) with the following settings: $95^{\circ} \mathrm{C}$ for 10 minutes, 40 cycles at $95^{\circ} \mathrm{C}$ for 15 seconds, and $60^{\circ} \mathrm{C}$ for 1 minute. Results were interpreted as recommended by the manufacturer.

Mutations were detected by next generation sequencing (NGS). The Ion Torrent system (Life Technologies) was used to analyze NGS libraries prepared by the NextDaySeq-lung Cancer Library Preparation Panel Kit (Beijing ACCB Biotech). Briefly, pooled primers were used to amplify the genomic regions of the exons noted above, followed by ligation with adapters and barcodes. After purification, libraries were quantified by a Qubit dsDNA HS Assay Kit and a Qubit 2.0 fluorimeter (Life Technologies, Carlsbad, CA, USA), diluted to a concentration of $3 \mathrm{ng} / \mathrm{mL}$, and pooled in equal volume. The pooled library was clonally amplified via emulsion PCR using ion sphere particles, and templatepositive particles were enriched by an Ion OneTouch 2 system (Life Technologies) as specified by the manufacturer. After enrichment, sequencing primers and the polymerase were added (PGM Sequencing Supplies 200 v2 Kit; Life Technologies). The libraries were loaded onto an ion 318 chip (Life Technologies) and sequenced by an Ion Torrent system. Variants were identified and annotated by a proprietary DanPA bioinformatics pipeline (Beijing ACCB Biotech).

As a confirmative method, Sanger sequencing was performed. Genomic regions of EGFR exons 18-21, $K R A S$ exons 2 and 3, PIK3CA exons 9 and 20, and $B R A F$ exons 11 and 15 were amplified from the DNA samples. Each exon was sequenced bidirectionally using the same primers as used in the initial amplification reaction and the ABI Prism Big Dye Terminator v 3.1 Cycle Sequencing Kit (Applied Biosystems, Foster City, CA, USA). The 
results of the sequencing primer extension reactions were analyzed by an ABI 3130XL Genetic Analyzer (Applied Biosystems) according to the manufacturer's instructions.

The three methods were carried out in all specimen except the AD of case 2 in Group 1 because the limitation of tissue quality, only PCR was done to examine the mutation status of EGFR, KRAS, PIK3CA, and BRAF.

\section{ACKNOWLEDGMENTS AND FUNDING}

The authors thank the Histology Laboratory at Peking Union Medical Collge Hospital performed immunohistochemical studies of these cases; Beijing ACCB Biotech Ltd for completing the sequencing examinations.

\section{CONFLICTS OF INTEREST}

The authors have no conflicts of interest to declare.

\section{REFERENCES}

1. Stupp R, Monnerat C, Turrisi AT, 3rd, Perry MC, Leyvraz S. Small cell lung cancer: state of the art and future perspectives. Lung cancer. 2004; 45:105-117.

2. Adelstein DJ, Tomashefski JF Jr., Snow NJ, Horrigan TP, Hines JD. Mixed small cell and non-small cell lung cancer. Chest. 1986; 89:699-704.

3. Mangum MD, Greco FA, Hainsworth JD, Hande KR, Johnson DH. Combined small-cell and non-small-cell lung cancer. J Clin Oncol. 1989; 7:607-612.

4. Lemjabbar-Alaoui H, Hassan OU, Yang YW, Buchanan P. Lung cancer: Biology and treatment options. Biochim Biophys Acta. 2015; 1856:189-210.

5. Russo A, Franchina T, Ricciardi GR, Picone A, Ferraro G, Zanghi M, Toscano G, Giordano A, Adamo V. A decade of EGFR inhibition in EGFR-mutated non small cell lung cancer (NSCLC): Old successes and future perspectives. Oncotarget. 2015; 6:26814-26825. doi: 10.18632/ oncotarget.4254.

6. Watanabe S, Sone T, Matsui T, Yamamura K, Tani M, Okazaki A, Kurokawa K, Tambo Y, Takato H, Ohkura N, Waseda Y, Katayama N, Kasahara K. Transformation to small-cell lung cancer following treatment with EGFR tyrosine kinase inhibitors in a patient with lung adenocarcinoma. Lung cancer. 2013; 82:370-372.

7. Murgia C, Caporale M, Ceesay O, Di Francesco G, Ferri N, Varasano V, de las Heras M, Palmarini M. Lung adenocarcinoma originates from retrovirus infection of proliferating type 2 pneumocytes during pulmonary postnatal development or tissue repair. PLoS Pathog. 2011; 7:e1002014.

8. Lu HY, Mao WM, Cheng QY, Chen B, Cai JF, Wang XJ, Wang Z, Xie FJ. Mutation status of epidermal growth factor receptor and clinical features of patients with combined small cell lung cancer who received surgical treatment. Oncol Lett. 2012; 3:1288-1292.

9. Fukui T, Tsuta K, Furuta K, Watanabe S, Asamura H, Ohe Y, Maeshima AM, Shibata T, Masuda N, Matsuno Y. Epidermal growth factor receptor mutation status and clinicopathological features of combined small cell carcinoma with adenocarcinoma of the lung. Cancer Sci. 2007; 98:1714-1719.

10. Tatematsu A, Shimizu J, Murakami Y, Horio Y, Nakamura S, Hida T, Mitsudomi T, Yatabe Y. Epidermal growth factor receptor mutations in small cell lung cancer. Clin Cancer Res. 2008; 14:6092-6096.

11. Norkowski E, Ghigna MR, Lacroix L, Le Chevalier T, Fadel E, Dartevelle P, Dorfmuller P, Thomas de Montpreville V. Smallcell carcinoma in the setting of pulmonary adenocarcinoma: new insights in the era of molecular pathology. J Thorac Oncol. 2013; 8:1265-1271.

12. Zhu Q, Zhan P, Zhang X, Lv T, Song Y. Clinicopathologic characteristics of patients with ROS1 fusion gene in nonsmall cell lung cancer: a meta-analysis. Transl Lung Cancer Res. 2015; 4:300-309.

13. Oser MG, Niederst MJ, Sequist LV, Engelman JA. Transformation from non-small-cell lung cancer to smallcell lung cancer: molecular drivers and cells of origin. Lancet Oncol. 2015; 16:e165-172.

14. Zakowski MF, Ladanyi M, Kris MG. EGFR mutations in small-cell lung cancers in patients who have never smoked. N Engl J Med. 2006; 355:213-215.

15. Morinaga R, Okamoto I, Furuta K, Kawano Y, Sekijima M, Dote K, Satou T, Nishio K, Fukuoka M, Nakagawa K. Sequential occurrence of non-small cell and small cell lung cancer with the same EGFR mutation. Lung cancer. 2007; 58:411-413.

16. Alam N, Gustafson KS, Ladanyi M, Zakowski MF, Kapoor A, Truskinovsky AM, Dudek AZ. Small-cell carcinoma with an epidermal growth factor receptor mutation in a never-smoker with gefitinib-responsive adenocarcinoma of the lung. Clin Cancer Res. 2010; 11:E1-4.

17. Sequist LV, Waltman BA, Dias-Santagata D, Digumarthy S, Turke AB, Fidias P, Bergethon K, Shaw AT, Gettinger S, Cosper AK, Akhavanfard S, Heist RS, Temel J, et al. Genotypic and histological evolution of lung cancers acquiring resistance to EGFR inhibitors. Sci Transl Med. 2011; 3:75ra26.

18. Ma AT, Chan WK, Ma ES, Cheng T, Cheng PN. Small cell lung cancer with an epidermal growth factor receptor mutation in primary gefitinib-resistant adenocarcinoma of the lung. Acta Oncol. 2012; 51:557-559.

19. van Riel S, Thunnissen E, Heideman D, Smit EF, Biesma B. A patient with simultaneously appearing adenocarcinoma and small-cell lung carcinoma harbouring an identical EGFR exon 19 mutation. Ann Oncol. 2012; 23:3188-3189. 
20. Popat S, Wotherspoon A, Nutting CM, Gonzalez D, Nicholson AG, O'Brien M. Transformation to "high grade" neuroendocrine carcinoma as an acquired drug resistance mechanism in EGFR-mutant lung adenocarcinoma. Lung cancer. 2013; 80:1-4.

21. Facchinetti F, Tiseo M, Gnetti L, Silini EM, Ardizzoni A. NSE level in combined neuroendocrine and adenocarcinoma EGFR mutated lung cancer resistant to EGFR-TKI. Lung cancer. 2013; 82:177-178.

22. Hwang KE, Jung JW, Oh SJ, Park MJ, Shon YJ, Choi KH, Jeong ET, Kim HR. Transformation to small cell lung cancer as an acquired resistance mechanism in EGFR-mutant lung adenocarcinoma: a case report of complete response to etoposide and cisplatin. Tumori. 2015; 101:e96-98.
23. Furugen M, Uechi K, Hirai J, Aoyama H, Saio M, Yoshimi N, Kinjo T, Miyagi K, Haranaga S, Higa F, Tateyama M, Fujita J. An Autopsy Case of Two Distinct, Acquired Drug Resistance Mechanisms in Epidermal Growth Factor Receptor-mutant Lung Adenocarcinoma: Small Cell Carcinoma Transformation and Epidermal Growth Factor Receptor T790M Mutation. Intern Med. 2015; 54:2491-2496.

24. Niederst MJ, Sequist LV, Poirier JT, Mermel CH, Lockerman EL, Garcia AR, Katayama R, Costa C, Ross KN, Moran T, Howe E, Fulton LE, Mulvey HE, et al. RB loss in resistant EGFR mutant lung adenocarcinomas that transform to small-cell lung cancer. Nat Commun. $2015 ; 6: 6377$. 